\title{
SINFUL PROFESSIONS: ILLEGAL OGGUPATIONS OF WOMEN IN OTTOMAN ALEPPO, SYRIA
}

\author{
ELYSE SEMERDJIAN \\ University of Michigan, Flint
}

\section{Abstract}

What was the economic role of women in the Islamic world? Archival sources such as court records reveal that women were employed in a number of legal occupations as moneylenders, buyers and sellers of property, midwives, administrators of religious endowments (waqfs) and textile workers. On the other hand, women were just as active in illegal occupations as prostitutes, procurers of prostitution and distillers of alcohol. This study will show that punishment for crimes such as prostitution was light due to the fact that customers were often linked to the Ottoman military and government. Furthermore, all three occupations involved tax evasion; alcohol in particular was legal to distill for non-Muslims as long as it was properly taxed and produced within the all-powerful guild system. These crimes reveal the diversity of occupations within which women were employed and the standards of morality within the city of Aleppo.

The issue of women's work in the Islamic world conjures up images of contemporary crises involving women's exclusion from the political and economic sector. ${ }^{1}$ The power of a new patriarchal discourse on women's labor can be seen in the recent situation in Afghanistan in which the Taliban demanded that women return to their homes according to a newly instituted Islamic mandate. Yet it was probably the economic circumstances of a war-torn, economically devastated Afghanistan that drove these policy decisions since a large unemployed male population sought the jobs occupied by women. The result was that the Taliban's actions helped destroy the country's economic infrastructure by eliminating its female professional class which provided crucial services to Afghani society, not the least of which were educational, nursing and medical services.

1 This paper was first presented at a conference entitled "Women and the Labor Market: The Islamic World Past and Present" sponsored by the Islamic Legal Studies Program at Harvard University, May 2002. 
Algeria had also failed to protect women's right to work when passing its patriarchal Family Code in 1984, which was considered an ironic move given the crucial role played by women in the success of the Algerian revolution. Morality discourses have also played a major role in these policy formulations and have become central to the question of women's work. Since the political crisis that followed the hijacked elections in 1991, Islamic militants in Algeria have created new definitions of morality in which women who live alone, who are divorced, who smoke, or who wear blue jeans are profiled as loose women and targets of violence. For example, the Armed Islamic Group (Group Islamique Armée) known more by its acronym GIA "issued a statement classifying all unveiled women who appear in public as potential military targets" in $1994 .^{2}$ Included among these women openly displaying what are seen as "Western" and independent behaviors are working and professional women or women employed as school principals or women's rights activists. ${ }^{3}$ In her work, Karima Bennoune provides several examples of women attacked by Algerian extremists throughout the 1990s; the brutal attacks involved rape, torture, harassment, and often murder. She writes that, "on an ad hoc basis, fundamentalists implemented their ideological agenda by harassing women who were merely trying to practice their professions." ${ }^{4}$ This included, for example, threats against female medical workers if they attempted to wash their arms in order to enforce medical standards of hygiene in the work place. The profiling of working women continues in other countries such as Pakistan where professional women such as Farhat Sadiq, a nurse who worked the night shift at the local hospital, was targeted and raped at gun point because she fit the profile of a loose woman by working at night. She was subsequently sent to prison in Karachi for being a "prostitute" while the three men who gang raped her walked away unscathed. ${ }^{5}$ Although no definitive academic studies

\footnotetext{
2 Karima Bennoune, "The War Against Women in Algeria," Ms. Magazine, September/October 1995, 22.

${ }^{3}$ Ibid.

${ }^{4}$ Karima Bennoune, "S.O.S. Algeria: women's human rights under siege," in Faith and Freedom: Women's Human Rights in the Muslim World, ed. Mahnaz Afkhami (New York: Syracuse University Press, 1995), 195.

5 "Women Jailed," Marie Claire, October, 1996, 74.
} 
have focused on this topic, some have speculated that several female prisoners in Pakistan are in fact rape victims whose attackers have testified against them - a practice that outrightly defies zina law in $\operatorname{shart}^{-} a$ according to which the male party should also be punished. The result is a new mutated form of Islamic law being practiced in several Muslim countries today. These contemporary realities have led researchers to probe the historical practice of law to better understand the position of women in Islamic history.

The contemporary backlash against working women in parts of the Islamic World presents Muslim women as excluded from the labor market. Yet, contemporary crises over the right to work need to be placed within the context of women's vibrant historical position in the economy of the Middle East. This study will look at the issue of morality and women's labor from an historical perspective in an attempt to contextualize the historical experience of women and work in Ottoman Aleppo, Syria. It will focus on illegal occupations in which women were actively employed. Illegal occupations are a point of focus since they offer an alternative discourse to the notion that women in the Middle East were restricted in their social and economic options. In fact, women were employed in a number of legitimate and illegitimate industries, which demonstrates their permeation within several sectors of society. In particular, this article will look at women's participation in work as prostitutes, procurers of prostitution and distillers of liquor represented by court cases from the Islamic courts of Aleppo. These three professions, which were not only present but also prevalent in Ottoman Syria, were professions of the lowest order.

The article will also focus on how these professions were treated in the Islamic courts of Aleppo, which reveals the perceptions of morality in the Ottoman period, the willingness to police and punish these crimes, and the presence of the Ottoman State in these matters. This study concludes that, in the Ottoman period, local communities, not the state, policed these crimes. Policing was performed by the residents of city quarters, mostly due to the ineffectiveness of the Ottoman police. Neighborhoods would come together along with neighborhood representatives and bring the offender to court. Abdul Karim Rafeq calls this group action used to police the city neighborhoods of Damascus "quarter solidarity" and the court records reveal that it was the method of policing the quarters of 
Aleppo as well. ${ }^{6}$ Most often the punishment was non-corporal and took the form of removal from the city quarter where the offender resided. A city quarter was a very small area, with only a few feet between one quarter and the next, so these punishments constituted the proverbial "slap on the wrist". A demonstration of the flexibility exercised and the use of non-violent punishments in these cases, makes the usual myths about the nature of Islamic law dismissible. There is often an assumption that Islamic law, unlike other codes of law, is somehow exceptional and does not deviate from the text when applied in practice. For example, it is assumed that since Islamic juridical writings ( figh) and the Hadìth (traditions of the Prophet Muhammad) endorse stoning as a punishment for fornication $(z i n \bar{a})$, the letter of the law was applied in local societies. This assumption is not very different from the Orientalist argument that Islamic law has not developed beyond the ninth century, a paradigm often referred to as the "closing of the gates of $\ddot{j} t i h \bar{a} d$ ". This exceptionalism is also present in the contemporary discourse of Islamists and religious purists who demand that Islamic law must be practiced in accordance with the earliest Islamic texts and their prescriptions of punishment, which are often corporal. This study will call both these arguments into question. In the Islamic court records from Aleppo there is no evidence that corporal punishment was ever practiced in cases of prostitution, procuring or distilling of liquor. In that local practices of law entailed non-violent punishment for offenders, it suggests that prostitution was a practice that persevered in Aleppo and was given the "green light" by the legal authorities. It is possible that there was a reluctance to implement violent punishments in prostitution cases because it often involved entire households. Husbands, wives, mothers-in-law, sisters and brothers often procured prostitution together within the same household. The fact that it was a family business flies in the face of the traditional moral values of the Islamic world and suggests that there was a socio-economic need for families to engage in the

\footnotetext{
${ }^{6}$ The term "quarter solidarity" is used by Abdul Karim Rafeq in his article "Public Morality in 18th Century Damascus," Revue du Monde Musulman et de la Méditerranée 55/56 (1990): 180-96.

${ }^{7}$ Joseph Schacht, Introduction to Islamic Law (London: Oxford University Press, 1964), 69.
} 
practice whether for primary or supplemental income. Local chronicles also illuminate the fact that government officials and soldiers were often the patrons of prostitutes in Ottoman Aleppo. These factors may have contributed to the failure to prosecute prostitution with the full force of the law; judges opted instead for non-violent punishment often in the form of removal from city quarters. This punishment left prostitutes and procurers the option to relocate in another quarter located only a few feet away.

Islamic court records are the main source of this study and are records of actual court cases written by court scribes in the Islamic courts. The Islamic courts were located in several key urban areas throughout the Ottoman Empire; for Syria there are records for the cities of Aleppo, Damascus, Hama and Homs. The records for Aleppo sometimes contain direct quotes from plaintiffs and defendants. Often the records are formulaic and use repetitive phrases to convey the cases. It is impossible to know whether the formulaic phrases used in the court records were devised by the plaintiff, the judge or the scribe; furthermore many details from the crimes are missing from the documents, which sometimes leaves historians with only fragments of the larger picture. What Islamic court records do offer is a piece of a larger puzzle unlocking particular aspects of social life in the Ottoman period. These records are rich in information concerning women's work. Women were involved in a number of legitimate industries such as buying and selling property. Women were selling houses, and on occasion donating their property for religious endowments (waqf). Women worked at spinning silk and cotton in their homes as lower artisans and would often own one or two looms. ${ }^{8}$ They would spin silk and cotton thread in their homes with raw materials provided by a contractor in a system of cottage industry akin to that in other early modern economies. Haim Gerber writes of women in the silk industry in Ottoman Bursa, another major city center along the silk route:

Most women artisans were probably engaged in a cottage industry and their involvement seems to have been more substantial. It was also called the "putting out system," a system of production in which

8 Alexander Russell, A Natural History of Aleppo, vol. 1 (London: G.G. and J. Robinson, 1794), 162. 
the actual producer is dependent on a merchant financier for the provision of raw materials and for marketing, but still works at home with his or her own tools. ${ }^{9}$

Judith Tucker's work on women in nineteenth-century Egypt describes women's work in the textile industry in detail, in particular their participation in cottage industries which allowed women to be near their families managing housework and spinning side by side. ${ }^{10}$ Tucker specifically traces this pattern through time, noting the impact that the influx of cheaper, more durable machine-made textiles from Europe had on Egyptian women's economic welfare. On occasion women would get more involved in the silk economy of the Levant by buying and selling mulberry trees to other women who eventually sought to invest in silk worms in order to participate in the booming silk economy of the sixteenth and seventeenth centuries.

Women also worked as moneylenders, which was a lucrative trade. Since there were no public banks, most loans were made by private individuals at their own personal interest rates which could range to as high as 20 per cent. Gerber writes that "some women were so involved in credit transactions as to suggest that they were engaged in moneylending on a semi-professional basis." 11 The fact that there was a prohibition against usury in Islamic law did not seem to deter women from the desire to make a comfortable profit. "Sometimes women lent out money or gave credit to relatives and even outsiders." $"$ Certainly some transactions went unrecorded, but many were recorded when debts were not paid and the lender appeared in court to sue for compensation. Often the debtor was a relative of the woman lender. Gerber's study of Ottoman Bursa reveals how many estate records recorded that men sometimes died

${ }^{9}$ Haim Gerber, "Position of Women in an Ottoman City, Bursa, 1600-1700," International Fournal of Middle Eastern Studies 12 (1980): 237.

${ }^{10}$ Judith Tucker, Women in Nineteenth-Century Egypt (New York: Cambridge University Press, 1985).

${ }^{11}$ Gerber, "Position of Women," 234.

12 Ronald Jennings, "Women in Early 17th Century Ottoman Judicial RecordsThe Shari'a Court of Anatolian Kayseri," Fournal of Economic and Social History of the Orient 18:1 (1975): 102-3. Jennings' and Gerber's articles were the first to document women's economic activity in the Ottoman Empire using court records. Several records listing women as moneylenders to their husbands are found in Haim Gerber's "Position of Women," 234ff. 
owing money to their wives. ${ }^{13}$ Furthermore, according to Ronald Jennings in his study of Ottoman Kayseri, several cases reveal that men recorded payment of debts to their wives in court. Women had unique access to moveable capital, gold given to them as dowry by custom and property inherited from their relatives, that gave them the necessary startup capital for this enterprise. Even without personal investment, women appeared in court as guarantors of loans between two different parties. ${ }^{14}$

Not much research has been done on midwifery as an occupation in the Middle East, but there is evidence suggesting that there were guilds of midwives in the early modern period. ${ }^{15}$ Midwives served expectant mothers in the community but also appeared in the courts on occasion as expert witnesses in cases of rape and virginity testing. It was the principle role of midwives to inspect women in cases of rape to prove forced entry in order to gather evidence to be used in court. Midwives were also employed to verify the virginity of girls whose virginity was questioned by bridegrooms. For example, in one $1642 / 1052 \mathrm{H}$ case four midwives (qābilāt) appeared in court, and one midwife was described as Shaykha Fāṭima bint Shaykh Mustafa. The fact that Fātima is given the title shaykha denotes that she was the head of the guild of midwives in Aleppo. The midwives testified that they examined Karīma bint Hāāj Yūsif al-Mu'âșirānī and she was found to be a 'girl' (bint), a term that confirms she was indeed a virgin. ${ }^{16}$

There are a number of examples that demonstrate the extent of women's involvement in the labor force as active rather than passive agents. Along with legal industries, women were just as active in illegal professions. Some crimes, such as prostitution, violated both the law and standards of morality. Furthermore, these professions often operated outside of the guild system, making them a violation of labor laws in the Ottoman Empire since all labor was

13 Gerber, "Position of Women," 234.

14 Jennings, "Women in Ottoman Judicial Records," 103.

15 A recent dissertation from Georgetown University has explored the changing position of midwives in the Middle East noting the displacement of midwives by doctors in the late nineteenth century. See Hibba Abugideiri, "Egyptian Women and the Science Question: Gender in the Making of Colonized Medicine, 18931923," dissertation, History Department, Georgetown University, 2001.

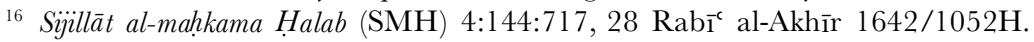


to be organized through the guilds to ensure proper taxation. The medieval guild institution was maintained throughout the Ottoman period since it offered an organized way for the authorities to collect taxes from the working population, mostly craftsmen and professionals. Although not much is yet known about the guilds and their history, Gabriel Baer's study of guilds in Egypt notes that two guilds for prostitutes were mentioned in the registers, but there is no further evidence suggesting that guilds existed for prostitutes in either Egypt or Syria for that matter. The $\operatorname{sharin}^{-} a$ court records for Aleppo make no reference to guilds of prostitutes. In the court culture of Aleppo, all existing guilds are referenced in the court records upon the appearance of a guild-member; the name of the member was always followed by the name of the $t \bar{a}^{\prime}$ ifa (guild) to which he/she belonged. The fact that prostitutes were involved in a number of cases and guilds were not mentioned after their names suggests that there were no prostitute guilds in Aleppo. It follows that professions such as prostitution, the procurement of prostitutes and private distillation of alcoholic beverages in the home escaped taxation by the Ottoman authorities since they were occupations outside the organization of guilds. It was permitted for non-Muslims to consume alcohol as long as it was not distributed to Muslims. Non-Muslim neighborhoods even had within them taverns where wine and liquor were served. Evidence used in this study suggests that private distillation was policed because brewing, distillation and distribution was not allowed to take place privately, but only in government-sanctioned spaces of taverns and distilleries. It is important to note that all cases concerning production of alcohol used in this study have non-Muslim defendants.

Cases of prostitution, procuring and distillation of liquor may have been brought to court in order to reassert Ottoman control over those guilty of tax evasion, but these cases were not brought to court by the Ottoman authorities but by local neighborhoods. These cases in which neighborhoods "policed" illegal workers could have been raised because of competition in the marketplace since sex workers and illegal distillers operated outside of the guild system. The guilds were formed in part to control the way in which goods were produced and to maintain a balance of competition in the market place. They played an important role in Ottoman administration since they were in charge of collecting taxes that would 
be handed over to the Ottoman authorities. By evading taxation those who worked in non-regulated illegal professions may have enjoyed a better profit margin, paying less overheads than tax paying laborers within the guild system.

Studying these professions is also useful since prostitution and liquor were direct violations of Islamic notions of morality and the way they were dealt with tells us about social attitudes towards morality and the administration of the law in the Ottoman period. The way these crimes were treated in the Islamic courts reveals the sensibilities of a city like Aleppo and its residents. All the women who were apprehended for distilling alcohol in their homes were, according to court records, non-Muslims and were not working within the guilds and therefore were not paying taxes. Furthermore, information about women's roles in the public and private spheres of the city, even within illegal professions, builds a more rounded image of women in the Middle East.

\section{Prostitution}

Prostitution is classified as a zina crime in Islamic law. Zina is loaded with multiple meanings, to the extent that this single term encompasses several modern crimes under a single legal category, describing as it does any type of sexual intercourse outside of the marriage contract. This includes adultery by married parties, both male and female, and sexual intercourse by unmarried people. Homosexuality is also a $z i n \bar{a}$ crime, usually described in the juridical texts specifically as male homosexuality or the act of sodomy, a definition that noticeably excludes female homosexuality. The Ottomans included abduction of young boys or girls as a category of zina since it was often for the purpose of sex or elopement. Abduction was a particular concern, especially in the sixteenth century, during which tribal raids in Anatolia were common and involved the pillaging of property and abduction of women and children as part of the booty looted throughout the countryside. Although there were kanunname written for each province (vilayet) of the Ottoman Empire, the eightpage kanunname for the liw $\bar{a}$ ' (administrative section) of Aleppo does not discuss criminal matters. ${ }^{17}$ For that reason this article looks to

${ }_{17}$ The kanunname of Aleppo from 1570 to $1571 / 978 \mathrm{H}$ are found in the başkaban- 
the Anatolian kanunname for details concerning criminal matters. On the issue of abduction, the Ottoman Imperial Kanunname of Selim I (1512-1520) calls for the severe punishment of castration for a man who abducts a girl or woman by force. ${ }^{18}$ The codes attempt to further discourage this practice and state that if the kidnapper and the abducted girl or woman attempt to marry and are successfully married by an imam or spiritual leader, the imam is to have his beard cut off according to the kanunname. Another zina crime, according to jurists, was bestiality; this was a favorite topic for Islamic jurists to contemplate since it presented the complicated issue of sanity. Bestiality as a crime demanded that the sanity of the perpetrator be considered. In other words, a sane person would not engage in such an act, and the insane are not to be punished for zina according to Islamic law. The juridical writings concur that bestiality is something performed by the insane and is not punishable. It is important to mention that there were no cases of bestiality in the court records of Aleppo from samples taken between 1550 and $1900 .^{19}$

Important for this study, the crimes of prostitution and procurement of prostitution were included under the zin $\bar{a}$ category. The Islamic jurist al-Marghinān̄ (d. 1196) wrote that prostitution is "the ugliest form of zinā." 20 A pimp (or madame) was accused of zina crime as if she were the actual participant, according to the juridical writings. Ottoman law also considers the procurement of prostitution (püzavinklik), in which someone forces a person into

lök archives in Istanbul, Turkey and are labeled Tapu Tahrir \#493. I would like to thank Charles Wilkins for giving me a copy of it.

18 "Siyasat için sikra kisla" is what the Kannuname call for, which literally means "his manhood should be cut." See Selami Pulaha, and Yaşar Yücel, Derbeyān-i Kānūnnāme-i 'Osmānn̄, Belgeler: Türk Tarih Belgeleri Dergisi XII, 16 (Ankara: Türk Tarih Kurumu Basömevi, 1987), 51. This law is also found in the Kannuname of Suleyman where abduction of a young boy is punishable by castration or a fine of 24 gold pieces. See Uriel Heyd, Studies in Old Ottoman Criminal Law, ed. V.L. Menage, (Oxford, London, 1973), 136.

19 This research entailed sampling one sijill or volume of court records for every decade from 1550-1900. These sijills contain 2-3 years of court records in each bound volume.

${ }^{20}$ Al-Marghinānī, Imām Abū Bakr al-Farghānī, Al-hidāya sharh bidāyat al-mubtad $\bar{\imath}$, vol. 2 (Beirut: Shirkat dār al-urqam bin abī al-urqam), 387. 
prostitution, as a crime more serious than prostitution itself. ${ }^{21}$ In fact, prostitution as a crime is not even mentioned in the Ottoman Kanunname.

Islamic jurists advocated very strict prescriptions to punish the crime of zin $\bar{a} .{ }^{22}$ The punishment for an unmarried offender is 100 lashes. ${ }^{23}$ The juridical writings on the topic cover this in detail, including how the lashes are to be administered on the back, widthwise instead of length-wise so as to minimize damage to the offender. Furthermore, al-Marghinānī is specific in mandating that an offender not to be lashed on "his face or privates." 24 A married offender is to be stoned (rajm) until dead. ${ }^{25}$ The juridical literature is also specific as to how this punishment is to be carried out. In the $\operatorname{sharl}^{-i} a$ punishment is not directed at the female participant alone, as in some contemporary Islamist interpretations in places such as Iran, Pakistan and Afghanistan. The $\operatorname{sharin}^{-} a$ is specific that both parties are to be punished by stoning for zina including the male participant if he is married. During the punishment a man is to be set loose, unbound while he is stoned to death. A woman is to be buried up to her shoulders and stoned so as to inflict more damage on the head in accordance with Hadith in which, during the lifetime of the Prophet, Ghamdia was buried to her shoulders then stoned, and Shoraha was stoned similarly under Caliph 'Ali. ${ }^{26}$ The details of the juridical writings are mentioned only to illustrate how specific they are; it is noteworthy that not one instance of stoning was found in the court records examined for this study.

In Aleppo, prostitutes were visible in court records and were brought to court quite regularly for their activities, usually by large groups of neighborhood representatives who would appear in court and use a number of descriptive terms and euphemisms to describe

${ }^{21}$ Colin Imber, "Zina in Ottoman Law," Collection Turcica III: Contribution a l'Histoire Economique at Sociale de l'Empire Ottoman (Leuven: Peeters, 1983), 81.

22 The topic of prescriptions of punishment for zina is discussed in more detail in chapter two of my dissertation entitled, "OOff the Straight Path': Gender, Public Morality and Legal Administration in Ottoman Aleppo, Syria," Georgetown University, 2002.

23 Al-Marghinān̄̄, Al-hidāya, vol. 2, 384; Schacht, Introduction to Islamic Law, 178.

24 Al-Marghinān̄̄, Al-hidāya, vol. 2, 385.

25 Ibid., 383-4.

${ }^{26}$ Ibid., 385. 
the activity of the woman in question. They would then petition for the removal of the woman from their neighborhood. If the court found the claim to be supported by the testimony, it would advocate the removal of the woman from the neighborhood. Removal or banishment from the city quarter appears to be the only punishment administered against these women in the courts of Aleppo. In fact, on occasion harsher punishments were meted out than were given to prostitutes. This included flogging ( $t a^{c} z \bar{\imath} r$ bi-al-darb) for pronouncing insults in the street. For example, in 1663/1073H Wafā bin Darwīsh insulted Ḥājj Muhammad bin Ismāễl by calling him "the husband of a whore" (zawj al-qahba). Hājj Muhammad brought with him four witnesses. In the end Wafā was given $t a^{c} z \bar{\imath} r$ for insulting but the form the punishment took was not designated. ${ }^{27}$ In another case a group of Christians were apprehended for being drunk and insulting Muslim residents in the neighborhood of Almājī. Their punishment for that offence was beating ( $t a^{c} z \bar{\imath} r$ bi-al-darb). Sometimes a particular euphemism was used in the records describing women as "vicious tongued" (salītat al-lisān) or "lengthening her tongue" (titawwil lisānaha). Describing a woman as "long-tongued" meant that she was either pronouncing or defying the reasonable limits of what a woman should say in public and this reflects social attitudes concerning the moral limits for women in Ottoman Aleppo. It is important to note that accusations of being "long-tongued" were directed only at women. Interestingly, in these cases "longtongued" women were removed from their neighborhoods, as were prostitutes. In one 1679/1089H case, Amīna bint 'Abdallāh was removed from the neighborhood of Dabbāgha al-'Atīqa for harming the residents and for "always lengthening her tongue at her neighbors." 28 Although this case seems to be a case of pronouncing, it may have included other crimes within the euphemism of "harmful" which are not fully apparent in the document. Banishment or removal of a resident was usually from the neighborhood and on rare occasion from the city. On the other hand, neighborhoods were very small; so being ejected from a neighborhood allowed the possibility of relocating a few doors away.

Here I am suggesting that using euphemisms was a technique

27 SMH 28:651:2376, 28 Rajab 1663/1073H.

${ }^{28} \mathrm{SMH} 34: 109: 491,6$ Dhu al-Qa'da 1679/1089H. 
used to avoid corporal punishment by the court. Importantly, the court records are a synopsis of events and use specific and repetitious language to describe these crimes. Did the plaintiffs also use the same descriptions? The answer to that question may never be known, but what we do know is what the courts recorded, which was often in formulaic terms. The records use terms such as "evil doer" (sharrīra) or "off the straight path" ('alä ghayr al-țarīq al-mustaqim) to describe prostitutes and procurers, depending on the context. By encoding crimes with euphemisms the courts deviated from the standard categories of Islamic law and created a legal loophole by which violent corporal punishment could be avoided.

While a woman might be described as immoral ( fäjira), the records need to be read in context to discern that it is a description of a prostitute since often the cases are cloaked in euphemisms. In a case from $1660 / 1071 \mathrm{H}$ a woman whose name is simply recorded as Zahra by the court scribe was brought to court on charges of prostitution by the residents of her neighborhood, Jāmic 'Ubays. The record shows that the neighbors complained that Zahra was an "evil doer", "mischievous" and a woman "off the straight path". The document relates "that she brings strange men into her home" which is a common euphemism used to indicate a brothel. In this case it appears that she had a one-woman operation. ${ }^{29}$ Cases of this type were common in the courts of Aleppo and the punishment was uniformly prescribed as removal from the city quarter unless the prostitute was involved in multiple criminal behaviors besides prostitution.

Other types of cases that appear in the courts of Aleppo are those that I call "confessionals". They are cases of reformed prostitutes who appeared in court to confess that they had once strayed but were now returning to a moral way of life. One case was of a woman, Khadija bint Shaykh Șalāh, who in 1762/1175H appeared and confessed that she had been "from among the women who perpetrate sins" and had now turned towards God. Interestingly, the same record shows that she was married to Muștafā bin 'Alī who offered her a typical dowry for that period, 10 quru $\bar{s} h .^{30}$ Another reformed prostitute, Fāțima bint Lughd al-Sarrāj, in 1851/1267H

\footnotetext{
${ }^{29}$ SMH 28:18:63, 21 Muharram 1660/1071H.
}

30 SMH 94:81:167, 4 Ramaḍān 1762/1175H. 
appeared in court confessing that she was no longer a prostitute and had married Hasan bin Muhammad al-Balūbī with a 1,250 quru $\bar{s} h$ dowry, 50 qurussh being paid in advance as the preliminary dowry. ${ }^{31}$ These cases are noteworthy because under Islamic law these women should still have been punished since confession was not enough to dismiss the crime. These cases further demonstrate the flexibility of the law and the difference in local interpretation of Islamic law in Aleppo as compared with written prescriptions in juridical writings.

\section{Proguring Prostitution}

The Kanunname of Selim I states that "if a person is procuring, the judge will make discretionary punishment, and will parade him or her publicly, and a fine of one akçe for every two strokes should be taken." ${ }^{32}$ Procurement of prostitution warranted a more severe punishment than prostitution as stated earlier. On rare occasions brothels were described forthright as "whore houses" (bayt al-qahba) in the court records. ${ }^{33}$ Yet, overall, the procurement of prostitution in the court records is described through euphemism. Terms such as the "gathering" or "mixing" of strange men and women in their homes, is used to describe brothels in the court records. The term "strange" or ajānib in Arabic means anyone who is not married or a relative within acceptable degrees, meaning someone who is not a relative forbidden in marriage. This would mean that even a first cousin, who is permissible in marriage, would have the status of a stranger.

One aspect of procuring in Ottoman Aleppo was that many times the procuring was done by couples or family members, as in the case of a couple who were removed from the neighborhood of alBandara. In this 1776/1190H case Sayyid Aḥmad bin al-Hājj Muḥammad and his wife Khadīja bint Bakrī were ejected from alBandara for their disgraceful $\left(\operatorname{shant}^{-} a\right)$ behavior in that they would gather women with Muslim and Christian men in their home. The term "gathering strangers" describes the operation of a brothel. The residents stated:

\footnotetext{
${ }^{31}$ SMH 261:3:5, 12 Jumādā al-Akhīra 1851/1267H.

${ }^{32}$ Pulaha, and Yücel, Derbeyān-i Kānūnnāme-i 53.

${ }_{33} \mathrm{SMH}$ 64:172:495, 6 Rajab 1741/1154H.
} 
The two pimps procured men and women in their house of residence in our neighborhood [and] performed evil and sin. They gather non-Muslim men in their home with strange women and harm us that way with their words and deeds. We are harmed by them and their disgraceful behavior. ${ }^{34}$

One of the women who worked in the brothel, a Christian woman named Miryam testified against them in court and gave her account of their activities. ${ }^{35}$ Miryam, who was identified as one of the women who "gathered" in the brothel with non-Muslim and Muslim men, testified against Sayyid Ahmad and Khadīja. Miryam remained unpunished while the pimps were targeted and removed from the quarter. Miryam's testimony alone would not have been enough for a conviction since non-Muslim (dhimm $\vec{\imath})$ testimony did not carry as much weight as that of Muslims. The fact that the neighborhood representatives presented and testified in the case gave it enough weight for conviction.

Another family-run brothel appeared in a $1687 / 1098 \mathrm{H}$ case that concerned a man by the name of 'Aqīl bin al-Hājj 'Uthmān who was brought to the court with his sister Hinna and his mother Alīfa. The residents of the street of al-Shimālī brought them to court since the family had been "gathering strange women and men in their home" which is again the euphemism for running a brothel. Without delay the residents petitioned for the removal of the family from the street of al-Shimālī on the basis that they were harmful to the neighborhood. ${ }^{36}$ The court ruled that they be removed. Another case involved a two-woman operation in which Farj bint al-Hāijj Mușțafa and Gevher bint 'Atallāh were apprehended and ousted from the neighborhood of Shukr Aghā in 1687/1098H for running a brothel in Farj's home. They said that Kuhar also lived there and was "off the straight path." The two women were banished from the neighborhood. On rare occasions unrelated women would operate a brothel together as in the $1660 / 1071 \mathrm{H}$ case of three unrelated women removed from the neighborhood of Sajilkhān al-Taḥtāni ${ }^{37}$ More often relatives would work together in a brothel

${ }^{34} \mathrm{SMH}$ 113:128:304, 2 Muharram 1781/1196H.

${ }^{35}$ Ibid.

${ }^{36}$ SMH 36:24:67, I Jumādā al-Ūlā 1687/1098H.

${ }^{37} \mathrm{SMH}$ 28:108:464, $7 \mathrm{Rabī}^{\mathrm{c}}$ al-Awwal 1660/1071H. 
as in the case of Farah, Șūfiyya and Șāliḥa, three "mischievous" sisters removed from al-Qawānisa in 1660/1071H. ${ }^{38}$

These cases reveal a pattern of procuring and prostitution that was performed in private homes, not in institutions. There were some exceptions to this case, such as two cases in which pimps used bathhouses as fronts for prostitution. ${ }^{39}$ Another incident of procuring in Damascus appeared in the court records in which a cook used his restaurant as a front for a brothel. ${ }^{40}$ Coffeehouses were another place of prostitution, but exclusively male prostitution in which dancing boys lured clients into the café for coffee and other pleasures. ${ }^{41}$ Although men engaged in procuring prostitution with female family members and operated within private homes, male procurers had the option to operate outside the home. Court records demonstrate that women always worked within the space of the home rather than a public venue for procuring, while men were able to operate in either public or private spheres. The records also reveal that prostitutes conducted their business practices in private homes, but these women were definitely public persona.

The visibility of prostitutes in Ottoman Syria is best portrayed in chronicles such as that of al-Budayrī, a Damascene barber who documented the daily events of Damascus in his chronicle called Hawādith Dimashq al-yawmiyya. ${ }^{42}$ Drawing on his experience as a barber, al-Budayrî's chronicle offers a unique popular account of Damascene life during the eighteenth century. It is the only account of Ottoman Syria available that offers insight into the social life of the lower classes in that period. Within his discussion al-Budayrī describes prostitutes in Damascus as having a public presence, "strolling in the streets of Damascus and gathering in marketplaces". ${ }^{43}$ Furthermore, al-Budayrī wrote that prostitutes "staged public celebrations and walked unveiled while chanting and dancing" in this

${ }^{38}$ SMH 28:66:223, 14 Safar 1660/1071H.

${ }^{39}$ Two cases of procuring in Aleppo's bathhouses are found in SMH 55:48:162, 2 Rajab 1637/1047H.

SMH 45:73:177, 19 Ramaḍan 1718/1130H.

${ }^{40}$ Rafeq, "Public Morality", 182.

${ }^{41}$ Ralph Hattox, Coffee and Coffeehouses: The Origins of a Social Beverage in the Medieval Near East (Seattle: University of Washington Press, 1985), 109.

${ }^{42}$ Al-Budayrī al-Hallāq, Hawā dith Dimashq al-yawmiyya, 1154-1176H/1741-1763, ed. Ahmad 'Izzat 'Abd al-Karīm (Cairo, 1959).

${ }^{43}$ Rafeq, "Public Morality", 183. 
case "in fulfillment of a vow made by one of them to celebrate the recovery of her boyfriend from his illness". ${ }^{44}$ There were periodic bans on prostitution in the eighteenth century, but overall they were ineffective. In Damascus at times the governor would levy taxes upon prostitutes in order to raise more revenue. At one point in Damascus prostitutes were to be banished from the city under one governor, As'ad Pasha al-'Azm, while at the same time another government official, the treasurer Fathī al-Daftarī, invited prostitutes to attend his daughter's wedding. Al-Daftarī hosted a different social group from Damascus for each of the seven days of the celebration and assigned the seventh day to the prostitutes, giving them gifts. ${ }^{45}$ These examples reveal the public visibility of prostitutes and their linkages with patrons in government circles.

In some cases prostitutes were severely punished for some of their criminal behavior. Al-Budayrī describes a prostitute who attacked a local judge in the month of Muharram 1744/1157H:

It came to pass, that a prostitute (min al-banāt al-khāsssa) named Salmūn was quarrelsome in the street; she was drunk, with a visible face (unveiled) and held a knife in her hand. A group with the $q \bar{a} d \bar{\imath}$ shouted at her, "turn away from the street." In front of this judge she laughed, yelled and attacked the judge with the knife, and they separated her from him. Then the $q \bar{a} d \bar{\imath}$ gathered the governor $(w \bar{a} \bar{\imath})$ and tax collector (mutasallim) and related to them his situation with this whore and they told him that this was one of the prostitutes and her name was Salmūn and most of the people were infatuated with her ... and the mufti issued a fatwa calling for her death ... they investigated her and she was killed. ${ }^{46}$

Salmūn was executed for physically attacking the judge, an Ottoman official. But this case had temporary consequences on the life of prostitutes living in the city. Al-Budayrī adds that there was a governmental crackdown on prostitutes and the prostitutes began to leave Damascus while others formed an encampment on the outskirts of the city. On the other hand, Rafeq writes that "the ban on prostitutes was not maintained for long, and they were reported

44 Ibid.

45 Ibid., 190.

${ }^{46}$ Al-Budayrī, Hawādith Dimashq, 127. This case is also cited in Rafeq, "Public Morality," 183. 
in three consecutive years as strolling the streets of Damascus and gathering in marketplaces." ${ }^{47}$ The attempt to suppress prostitution in Damascus after the Salmūn incident seems to have been ineffectual and reveals the perseverance of prostitution despite periodic crackdowns.

In Ottoman Syria the court records provide evidence of tolerance of prostitution. The state did not regulate prostitution but evidently some government officials, including soldiery, were patrons of prostitutes. This may suggest its importance and function in Syrian society. In his history of Ottoman Aleppo, Abraham Marcus writes that, "prostitutes and pimps, highest on the list of local offenders, provided services too much in demand to be eliminated. Pushed out of one district they reappeared in another." ${ }^{48}$ Much of that patronage was with rebellious military officers some of them called irregular troops (levend) many of whom figured greatly in the crime world.

Prostitution was often a family affair in which brothers, sisters, mothers and husbands were involved together in the operation. I suggest that one reason why this crime might have included members of the immediate family is the nature of home life in the Ottoman period. Usually several members of the family, including married siblings, sons and daughters, shared the same social space. The houses were usually fashioned in a style referred to in Syria as bayt 'arabi (an Arab house) which has a courtyard ( $h \bar{u} s h)$ surrounded by several rooms attached to it. ${ }^{49}$ These houses, typical in the Ottoman period and in the old cities of the Arab world today, offer little privacy since all visitors must pass through the courtyard in order to reach the adjacent rooms. Although the homes were intended to offer privacy from neighbors with their high court walls, they did not offer much privacy within the home. Windows to the rooms surrounding the courtyard were placed on the ground level facing inward to ensure privacy from the outside world, but there was little privacy for the household itself. ${ }^{50}$ This meant that if a

\footnotetext{
${ }^{47}$ Rafeq, "Public Morality," 183.

${ }^{48}$ Abraham Marcus, The Middle East on the Eve of Modernity: Aleppo in the Eighteenth Century (New York: Columbia University Press, 1989), 328.

49 Ibid., 294.

${ }^{50}$ Abraham Marcus, "Privacy in 18th Century Aleppo," International Fournal of Middle East Studies 18 (1986), 169.
} 
member of the family were entertaining patrons in her room, the other family members would surely know that there was visitors. Therefore, in order for one family member to participate in this crime, it demanded the cooperation of the entire household.

Interestingly, some neighborhoods in Aleppo were gated and guards kept keys to lock up doors at night in order to keep strangers from entering the cul-de-sacs. ${ }^{51}$ This also made neighborhood privacy limited since visitors could be observed in such a restricted space. Due to the limits of privacy in such an environment, the operation of brothels must have been apparent immediately in gated neighborhoods. Although "Islamic law recognized unlicensed observation as offensive behavior" witnessing crime was another matter and obligated neighbors to work to stop it. ${ }^{52}$ The lack of privacy in the streets of the neighborhoods also begs the question of how long it actually took for neighbors to notice the entry of customers into brothels before it was stopped.

\section{DisTilling LIQUOR}

Alcohol is prohibited in the Qur'ān which states "shun as abominations drinking and gambling, and superstitions of all kinds." ${ }^{53}$ What is prohibited is not the alcohol so much as its mind-altering effects. Intoxication results from the fermentation of fruits and grains, therefore it is the process of khamr (to ferment) that is forbidden in Hadīth. Furthermore, Hadīth specifically prohibits the fermentation of grapes, raisins, honey, wheat, barley and dates. ${ }^{54}$

Intoxication or drunkenness is prohibited by jurists such as Imām al-Shāfíci, founder of the Shāfíi school of legal thought (madhhab), who said that "the drunk is one who departs from whatever he has in the way of mild virtue and tranquility (and goes) into (a state of) foolishness and ignorance. ${ }^{95}$ Hanafī writings have been used most in this study since the Hanafĩ school (madhhab) was the

\footnotetext{
${ }^{51}$ Marcus, Middle East on the Eve of Modernity, 283.

52 Ibid., 294.

${ }^{53}$ Qur’ān 5:90.

${ }^{54}$ Al-Bukhārī, Abū 'Abdallāh Muhammad ibn Ismā̄ēl, Saḥ̄h al-Bukhārī, trans. Muhammad Muḥsin Khān, Arabic and English, vol. 7 (Beirut: Dār al-'Arabiyya, 1985), 341.

${ }^{55}$ Hattox, Coffee and Coffeehouses, 56.
} 
school adopted by the Ottoman State and was the principal school applied in the major court of Aleppo, the Mahkamat al-Kubrā, where the cases for this study were found. With respect to drunkenness, Hanafì writings state: "the drunk who is to be punished is one who comprehends absolutely nothing at all, and who does not know a man from a woman, or the earth from the heavens." ${ }^{56}$ The juridical writings also state that since alcohol is a time sensitive substance, the offender is to be brought to court while still drunk or two witnesses are to testify to his/her drunkenness. The punishment for drunkenness is 80 lashes. ${ }^{57}$ Several cases of public drunkenness appeared in the court in the sixteenth century in which witnesses were brought to the court still smelling of liquor. These cases often describe Muslim defendants who were brought to court "smelling of alcohol". ${ }^{58}$ In addition, drinking alcohol was a crime with both moral and religious ramifications.

While prostitution and procuring were obvious violations of the Islamic moral code, distilling liquor was a profession legal for Christians and Jews and was tolerated by the Muslim authorities. Non-Muslims could serve liquor in exclusive taverns within neighborhoods known to contain a majority of non-Muslims. Travelers' accounts such as that of Alexander Russell, who passed through Aleppo in the eighteenth century, provide evidence that there were public distilleries in Aleppo. In fact, Russell notes the existence of a distillery in an undisclosed location in Aleppo where production had increased over the years. He also adds the increase in liquors imported from Marseilles into Aleppo. ${ }^{59}$ The account tells that Turks were still drinking much more than the residents in Aleppo, and some of the largest patrons of the taverns owned by non-Muslims were the Janissaries, or Ottoman soldiery. Russell writes, "The Janissaries in actual service, drink the most openly of all; their employment leads them much among the Christians and Jews, and

56 Ibid.

${ }^{57}$ Al-Marghinān̄̄, Al-hidāya, vol. 2, 399; Schacht, Introduction to Islamic Law, 178.

58 Some examples of cases of public drunkenness include Tāj al-Dīn bin alSayyid Ja'far al-Baghdādī recorded in the court register twice on the same day for drinking 'araq (an anise flavored liquor) and in the second case for smelling like liquor. See SMH 1:112:1063, 19 Shawwal 1555/962H and SMH 1:112:1064, 19 Shawwāl 1555/962H.

${ }_{59}$ Russell, Natural History, vol. 1, 183. 
brandy often proves a more effectual bribe with them than money." The chronicle states that most Muslims drank in secret within their homes so as to evade punishment by the authorities since the courts did not hesitate to prosecute. According to Ralph Hattox, most of the clientele of the taverns were "low-life dregs but this did not keep Muslims from venturing into those spaces especially Muslims of high standing who were above public condemnation." ${ }^{\prime 60}$

Often drunkenness was one crime committed in combination with others, as in the case of a Jewish woman in $1776 / 1189 \mathrm{H}$ by the name of Mulūk bint Hārūn from the neighborhood of al-Bandara who was brought to court on several charges. Eight Muslims bearing social titles from her neighborhood charged her with being an "evil doer" and claimed that she made harmful remarks towards the residents with her "vicious tongue" (salit tat al-lisān). Furthermore, the residents added that she distilled liquor in her home. For these violations they expelled her from the neighborhood. ${ }^{61}$

In yet another case from 1776/1190H, a Christian woman, Miryam bint Na'ma, was brought to court on charges of liquor distribution. The record tells that Miryam "was engaged in distilling liquor and selling it in her house of residence outside Bāb alNașr in Aleppo." ${ }^{92}$ At first glance we may think that Miriam was in trouble for distributing liquor on moral grounds, but that was not the case. The court was not looking to impose a heavy sentence on Miryam since, as a Christian, it was in her right to distill liquor and drink it as she pleased in private. The problem was that she was distributing a product outside of the all powerful guild system that regulated every facet of economic life in the Ottoman Empire. Miryam was in trouble because she was selling and distributing the liquor outside the guild which brought her to the attention of the authorities since she was not paying the taxes that all guild members were to pay; in fact the court refers to the customary taxes (takā $\bar{l} f^{\prime}$ urfiyya) usually paid on liquor. These customary taxes paid by the guilds were often irregular taxes levied to finance military campaigns. ${ }^{63}$ Miryam vowed not to produce any

${ }^{60}$ Hattox, Coffee and Coffeehouses, 78.

${ }^{61}$ SMH 113:1:3, 23 Dhū al-Hijja 1776/1189H.

${ }^{62}$ SMH 113:146:356, 20 Safar 1776/1190H.

${ }^{63}$ Abdul Karim Rafeq, "Craft Organization, Work Ethics, and the Strains of Change in Ottoman Syria," Journal of the American Oriental Society, 111:3 (1991) 507. 
more liquor as long as her debt in taxes could be removed. Her debt was subsequently forgiven.

One case involved a woman, Sīlā bint Samacān, a Christian tavern owner. She came to court in $1642 / 1052 \mathrm{H}$ where she testified that she had terminated her selling of intoxicating liquors. ${ }^{64}$ Tavern keepers like Sīlā bint Sama'ān were a non-Muslim, heterogeneous population, unlike coffeehouse keepers who were exclusively Muslim. There is no evidence indicating whether there was a guild of tavern owners in Aleppo, but her appearance in court may have been to relinquish her responsibility as a taxpayer since notarized documents often served a specific economic and social purpose. For instance, in Palestine and Syria it was common practice for a tax on taverns to be collected in the Mamluk and Ottoman periods. ${ }^{65}$ In order to remove her tax responsibilities she may have needed to register that she was leaving the profession. Tavern owners were not considered respectable, but neither were those who ran coffeehouses for that matter. "The tavern owner occupied roughly the same place on the social scale as the prostitute, the overt homosexual, and the itinerant entertainer." ${ }^{\prime 66}$ Sìla represented that population of the lowest professional class, but was the only case of a female tavern owner found in this research.

\section{Conclusion}

Women were employed in several illegal occupations as prostitutes, procuresses and distillers of liquor in Ottoman Aleppo. The evidence suggests that prostitutes and procuresses operated primarily within private homes. In that these women worked as prostitutes and procuresses in private homes, other relatives, male or female, would often work with them. Procuring was often a family business including brothers, sisters, mothers and husbands. We may speculate that this might have been the case because in such a private space, family cooperation was necessary for a successful enterprise. The

${ }^{64}$ SMH 4:130:678, 1 Jumādā al-Ūlā 1642/1052H.

${ }^{65}$ Ibid., 156-7 and Amnon Cohen, and Bernard Lewis, Population and Revenue in the Towns of Palestine in the Sixteenth Century (Princeton NJ: Princeton University Press, 1978), 68, 152, 169.

${ }^{66}$ Hattox, Coffee and Coffeehouses, 78. 
frequency of these cases suggests that it was a widespread profession that might have served an economic necessity especially since family members were incorporated into the process. Interestingly, the familial network within this profession worked against typical ideals of the Arab/Muslim family and conceptions of female honor. Socioeconomic concerns appear to have superseded concerns over female morality in Ottoman Aleppo and made prostitution a family affair.

Although distilling of liquor was something that could be done by Christians within the public sphere in distilleries and taverns, court records suggest that some women chose to produce liquor in their homes to evade the guild system and Ottoman taxation. On the other hand, Sīlā bint Sama'ān, the Christian tavern keeper, was legally employed working in a public space and most likely taxed for it. I suggest that women such as Sīlā were able to maintain operations that served alcohol as long as they did not distribute it to Muslims, paid their taxes to the state, and operated within the guild system. These cases reveal the fine line between legality and illegality revealing women's strategies of tax evasion to increase their profit margins.

What all three of these illegal occupations have in common is that the women employed in them were not paying taxes. First, there is no evidence that prostitutes or tavern keepers were organized into guilds in Aleppo. If they had been organized into guilds the records would have made reference to the guilds in either these cases or others. It is important to note that although there is no evidence of guilds of prostitutes for Syria, Gabriel Baer in his assessment of Egyptian guilds found that there were references to two guilds of prostitutes. ${ }^{67}$ Second, these professions' being outside the guild structure offered the women employed in them an opportunity to evade taxation. The fact that taxation of industry in the Ottoman Empire was a principal revenue generator placed these professions in a crucial position vis-à-vis the state.

Women working in illegal professions that dealt with liquor or prostitution did not suffer violent punishments, but instead received a token "slap on the wrist." These violations, considered among the worst crimes in Islam, were prescribed corporal punishments

${ }^{67}$ Gabriel Baer, Egyptian Guilds in Modern Times (Jerusalem: The Israel Oriental Society, 1964), 35 . 
in the juridical literature but these were not implemented in practice. The fact that non-violent punishments were administered for these crimes suggests several possibilities. I suggest that in Aleppo local customary practice of law ('urf) prevailed over the written letter of the law and it may be that zina $\bar{a}$ crimes were not viewed as deserving of flogging or the death penalty. Furthermore, it may have been perceived that the law was in accordance with the strict guidelines of the $\operatorname{sharin}^{-} a$ with respect to witnessing zina $\bar{a}$. A close reading of the $\operatorname{shar}^{-} a$ reveals that a true zina $\bar{a}$ case was difficult to prove: the very act of penetration had to be witnessed, and therefore these cases may have been perceived as different crimes from zina

Why was there such a sharp discrepancy between theory and practice with respect to zina $\bar{a}$ crime? It may be the use of euphemism that provides an answer to this question. Abdul Karim Rafeq argues that euphemisms were used to label crimes to conceal the damaging details since Aleppan society was one that valued privacy, in particular the privacy of the quarters of the city and families. An interesting question is whether the plaintiffs (primarily quarter residents) were the ones who determined the language of the case. If so, the euphemism could indeed be a way to ensure the privacy of details relating to the case. There are many possibilities with respect to the language used in the records. It is difficult to discern whether it was the courts or the plaintiffs that used the euphemisms to describe these crimes since the texts are often formulaic and interpretation was in the hands of the court scribe who recorded the events. But euphemisms, I argue, may have been used in order that lesser punishments than those prescribed in standard Islamic juridical writings should be meted out. It was easier to evade harsh and violent punishments when the courts avoided using specific legal language to describe the crime. Whether this encoding of crimes was a device employed by the courts or the plaintiffs it is difficult to say, but the courts did enforce the law accordingly.

Use of euphemism, as well as the tentacles of patronage with the social elite, governors and urban notable classes, kept these women from suffering the corporal punishments prescribed in Islamic juridical writings. Prostitution and the procurement of prostitution served a specific social purpose; the fact that family members were involved and the social practice in the courts was to mete out non-violent punishments despite juridical prescriptions for corporal 
punishment tells us that prostitution served a socio-economic purpose. It may have provided families with supplemental incomes. Prostitution also provided soldiers with female company and the power of their patronage ran as deep as the pockets of government officials who solicited their services.

\section{BIBLIOGRAPHY}

\section{Archival Sources}

Sijillāt al-Mahkama Halab (SMH) Islamic court records, Aleppo, Dār al-Wathä’iq alTārīkhiyya, Syrian National Archives, Damascus, Syria.

Kanunname Liwä’ Halab, Tapu Tahrir \#493, Başkabanlök Arşivi, Ankara, Turkey, 978H/1570-1571.

\section{Primary Sources}

al-Budayrī al-Hallāq. Hawādith Dimashq al-yawmiyya, 1154-1176H/1741-1763, ed. Ahmad 'Izzat 'Abd al-Karīm. Cairo, 1959.

al-Bukhārī, Abū 'Abdallāh Muḥammad ibn Ismā'êl. Saḥ̂̄h al-Bukhārū, trans. Muhammad Muhsin Khan, Arabic and English Edition, 9 vols. Beirut: Dār al-'Arabiyya, 1985.

al-Marghinān̄̄, Imām Abū Bakr al-Farghān̄̄. Al-hidāya sharh bidāyat al-mubtadì, 4 vols. Beirut: Shirkat dār al-urqam bin ab̄̄ al-urqam, n.d.

Pulaha, Selami, and Yaşar Yücel. Derbeyān-i Kānūnnāme-i 'Osmāñ̄, Belgeler: Türk Tarih Belgeleri Dergisi, XII 16. Ankara: Türk Tarih Kurumu Basömevi, 1987.

Russell, Alexander. The Natural History of Aleppo, 2 vols. London: G.G. and J. Robinson, 1794.

\section{Secondary Sources}

Hibba Abugideiri. "Egyptian Women and the Science Question: Gender in the Making of Colonized Medicine, 1893-1923." Dissertation, History Department, Georgetown University, 2001.

Baer, Gabriel. Egyptian Guilds in Modern Times. Jerusalem: The Israel Oriental Society, 1964.

Bennoune, Karima. "S.O.S. Algeria: Women's Human Rights Under Siege.” In Faith and Freedom: Women's Human Rights in the Muslim World, ed. Mahnaz Afkhami. New York: Syracuse University Press, 1995.

_. "The War Against Women in Algeria." Ms. Magazine, September/October 1995, 22-3.

Cohen, Amnon, and Bernard Lewis. Population and Revenue in the Towns of Palestine in the Sixteenth Century. Princeton NJ: Princeton University Press, 1978.

Gerber, Haim. "Position of Women in an Ottoman City, Bursa, 1600-1700." International Fournal of Middle Eastern Studies 12 (1980): 53-114. 
Hattox, Ralph. Coffee and Coffeehouses: The Origins of a Social Beverage in the Medieval Near East. Seattle: University of Washington Press, 1985.

Heyd, Uriel. Studies in Old Ottoman Criminal Law, ed. V.L. Menage. Oxford, London, 1973.

Imber, Colin. "Zina in Ottoman Law," Collection Turcica III: Contribution a l'Histoire Economique at Sociale de l'Empire Ottoman, pp. 59-91. Leuven: Peeters, 1983.

Jennings, Ronald. "Women in Early 17th Century Ottoman Judicial RecordsThe Shari'a Court of Anatolian Kayseri." Journal of Economic and Social History of the Orient 18:1 (1975): 53-114.

Marcus, Abraham. "Privacy in 18th Century Aleppo." International Fournal of Middle East Studies 18 (1986): 165-83.

. The Middle East on the Eve of Modernity: Aleppo in the Eighteenth Century. New York: Columbia University Press, 1989.

Rafeq, Abdul Karim. "Craft Organization, Work Ethics, and the Strains of Change in Ottoman Syria." Fournal of the American Oriental Society 11.3 (1991): 495-511.

"Public Morality in 18th Century Damascus." Revue du Monde Musulman et de la Méditerranée 55/56 (1990): 180-96.

Schacht, Joseph. An Introduction to Islamic Law. London: Oxford University Press, 1964 .

Semerdjian, Elyse, "Off the Straight Path: Gender, Public Morality and Legal Administration in Ottoman Aleppo, Syria." Dissertation, History Department, Georgetown University, 2002.

- "Gender Violence and Intent in Ottoman Law: A View of the Imperial Kanunnames and Fatwas of the Sixteenth Century." In A History of Her Own: Deconstructing Women in Islamic Societies, ed. Amira Sonbol, and John Voll. New York: Syracuse University Press, 2003, forthcoming.

Tucker, Judith. Women in Nineteenth Century Egypt. New York: Cambridge University Press, 1985.

"Women Jailed." Marie Claire, October, 1996, 74-7. 